\title{
DOS ESTATUTOS DA SOCIEDADE PORTUGUESA DE QUÍMICA
}

Artigo $1 .^{\circ}-\mathrm{A}$ "Sociedade Portuguesa de Químican tem por objectivo promover, cultivar e desenvolver, em Portugal, o ensino, a investigação e a aplicação da Quimica e das Ciências com esta mais directamente relacionados.

Artigo 2. ${ }^{\circ}$ - A "Sociedade Portuguesa de Quimica" tem a sua Sede em Lisboa e Delegações em qualquer ponto do território nacional onde se justifiquem. Por "Delegação" entende-se uma representação permanente da Sociedade, com actividade própria. A criação ou dissolução de Delegações depende de aprovação da Assembleia Geral da Sociedade Portuguesa de Química.

Parágrafo único - Consideram-se desde já criadas as Delegações de Coimbra, Lisboa e Porto.

Artigo $4 .^{\circ}$ - A "Sociedade Portuguesa de Químican tem cinco categorias de sócios: a) Sócios honorários; b) Sócios beneméritos; c) Sócios Colectivos; d) Sócios efectivos; e) Sócios estudantes. (...) Serão sócios colectivos instituições públicas ou privadas com actividade no dominio da Quimica ou de Ciências afins. Serão sócios efectivos individuos, nacionais ou estrangeiros, cuja actividade profissional se processe no dominio da Quimica ou de Ciências afins, ou que tenham dado provas de terem contribuido para o progres. so dessa Ciência ou para a realização de outros objectivos da Sociedade. Serão sócios estudan. tes os estudantes que se interessem pelo estudo da Quimica ou de Ciências afins.
Artigo $5 .^{\circ}$ - A admissão de sócios colectivos, efectivos e estudantes é feita pela Direcção da Delegação respectiva, devendo a proposta ser subscrita por dois sócios efectivos em pleno uso dos seus direitos.

Parágrafo primeiro - Os sócios colectivos, efectivos e estudantes podem escolher a delegação à qual desejam pertencer, sendo-Ihes também facultadas a transferência para qualquer outra Delegação quando o requeiram, com a única limitação de o fazerem uma só vez em cada ano social.

Artigo $7 .^{\circ}$ - A quota mínima anual dos sócios colectivos é de cinco mil escudos; a dos sócios efectivos é de trezentos escudos; e a dos sócios estudantes é de cento e cinquenta escudos.

(...)

Parágrafo segundo - As quotas deverão ser liquidadas durante o primeiro trimestre de cada ano. Caso tal não se verifique as regalias serão suspensas até ao pagamento integral das quotas em atraso.

Artigo $42 .^{\circ}$ - Poderão ser criados, na Sociedade Portuguesa de Química, "Divissões" com o objectivo de grupos de sócios com interesses cientificos afins.

Artigo $44 .^{\circ}-$ A coordenação das actividades de cada Divisão compete a um dos seus membros, eleito pelos sócios que se agregarem à Divisão. 